\title{
HOW FAR CAN RELIGIOUS EDUCATION CONTRIBUTE TO MULTICULTURAL/INTERCULTURAL EDUCATION?
}

\author{
Robert Jackson \\ University of Warwick \\ United Kingdom
}

\begin{abstract}
In this article the emergence in Britain (late 1960s) of a secular religious education $(R E)$, utilising material from the religions of the world and referring to its role in multicultural education in the 1970s will be given. Developments in the history of the relationship between multicultural and antiracist education (till early 1990s), when new critical approaches to multicultural education appeared, will be discussed. Policy discussions internationally are now recognising the importance of the religious dimension to intercultural education. New interpretive and dialogical pedagogies of religious education share similar analytic stances towards culture and religion and similar critical and reflexive methodologies to recent approaches to multicultural/intercultural education. Thus, religious education employing these pedagogies can make a direct contribution to an intercultural education working to promote social cohesion.
\end{abstract}

Key Concepts: Multicultural, antiracist, policy documents, interpretative approaches

\section{Introduction}

In England and Wales, at least until the late 1950s, religious education (RE) in publicly funded schools was a form of non-denominational Christian instruction that had moral and civic goals (Jackson, 2004:Chapter 1). This view of religious education began to change in the 1960s. By the mid 1960s, religious education scholars were criticising forms of RE in state funded schools that fostered religious belief or a religious outlook, on the grounds of the increased secularity of society and because research evidence showed that young people wanted an open and undogmatic study of religions in schools (Cox, 1967). By the late 1960s and early 1970s, Professor Ninian Smart and his team at Lancaster University had brought a global dimension to this secular form of RE through their introduction of the study of the religions of the world, using theory and method from the phenomenology of religion (Schools Council, 1971). At about the same time, religious educators in some of Britain's increasingly multicultural towns and cities were beginning to use local religious diversity as a resource for this new vision of the subject. They were also finding a role in promoting good community relations at the local level, and it is significant that one of the first books to explore religion in a multicultural and multifaith setting in Britain was published by a council for community relations (Cole, 1972). Many teachers of religious education joined the National Association for Multiracial Education, and RE was 
commonly regarded as a valuable contributor to multicultural education, along with other fields and subjects. ${ }^{1}$

Then there was a schism. This was between those with fundamentally antiracist concerns and those emphasising intercultural understanding (Mullard, 1984). The antiracists argued that multiculturalists had treated cultural issues superficially, unnecessarily reifying cultures and inadvertently emphasising difference (Troyna, 1983). Rather than promoting understanding, it was argued, multiculturalists were playing into racist hands by creating stereotypes of distinct, separate cultures. These were allowed limited forms of expression by the beneficence of a tolerant national culture (McIntyre, 1978). According to antiracists, multicultural education also avoided issues of power, explaining racism psychologically in terms of attitudes that could be changed through acquiring knowledge and learning tolerance, rather than through challenging accepted power structures within institutions. These inequalities of power were regarded as the real explanation for the perpetuation of inequality. Because of its concern with changing structures, antiracism gave limited attention to the curriculum, offering ideas to promote a critical awareness of institutional racism, for example, but not addressing issues of culture. Thus multicultural education, with multifaith religious education as a subset, and antiracist education had an uneasy relationship for some years, although some contributors continued to pursue the interests of both fields (e.g. Richardson, 1990).

It was not until the early 1990s that some writers began to heal the schism, recognising the need for an antiracist stance, but criticising antiracists for underestimating the importance of issues of cultural and religious representation, transmission and change. Multiculturalists were also urged to take a fresh look at these issues. These writers included Mal Leicester (Leicester, 1992) and Ali Rattansi (Rattansi, 1992), who appealed for reform through a synthesis of the two fields. Thus antiracist multicultural education (Leicester, 1992), critical multiculturalism (May, 1999:33) and reflexive multiculturalism (Rattansi, 1999:77) are critical of essentialist views of culture while acknowledging the role of power relations in cultural formation. In Rattansi's words:

...the multiculturalists will have to abandon their additive models of cultural pluralism and their continuing obsession with the old ethnicities. Antiracists...will have to move beyond their reductive conceptions of culture and their fear of cultural difference as simply a source of division and weakness in the struggle against racism (Rattansi, 1992:41).

\section{Multicultural Education Policy in the 1990s}

These developments, introduced in the early 1990s, remained unnoticed by politicians in government in Britain. Policy in England and Wales on the issue of multicultural education became clearly hard-line during the latter part of the period of Conservative Government between 1979 and 1997. In 1977, two years before the election of a Conservative Government, the Department of Education and Science promoted the recognition of Britain as a multicultural society and of education that recognised that fact. Our society is a multicultural and multiracial one, and the curriculum should reflect a sympathetic

The term multicultural education gained currency in Britain and in the USA, while intercultural education has been used more in continental European literature. Although the expression multicultural education has been criticised for its suggestion of closed and reified views of culture, in Britain it has remained the preferred term by some of those having much more sophisticated views of cultural discourse than the early multiculturalists. Intercultural education is being used more widely now in the UK, partly under European influence through Council of Europe projects and via the pages of this journal, for example. 
understanding of the different cultures and races that now make up our society (DES, 1977:41). The policy was maintained during the early years of the Conservative administration. For example, student teachers received training to teach in a multicultural society, in-service training courses were made available to serving teachers and GCSE examination boards ${ }^{2}$ had to take account of linguistic and cultural diversity. Moreover, money from central government was given to support projects on curriculum development for an ethnically diverse society (Tomlinson and Craft, 1995). However, despite positive rhetoric from Government sources, ${ }^{3}$ policies relating to the implementation of the National Curriculum eroded work in multicultural and antiracist education. Concern for equal opportunities and for providing information about cultural minorities disappeared in favour of a drive to raise standards, market competition, a regulated National Curriculum and testing. In a climate in which lobbyists from the New Right were influential (Ball, 1990), the Times Educational Supplement could judge that There seems to be a definite though unformulated intent to starve multicultural education of resources and let it wither on the vine (Times Educational Supplement 1990, A23). The Prime Minister of the day, John Major, declared at the 1992 Conservative Party Conference that primary teachers should learn how to teach children to read, not waste their time on the politics of gender, race and class. A year later, the former Chief Executive of the National Curriculum Council (what today is the Qualifications and Curriculum Authority) revealed that there had been specific instructions to remove references to multicultural education from the National Curriculum (Graham, 1993). Central Government's erosion of local education authority responsibilities for providing policy and financial support for what takes place in schools was also an important factor in the demise of multicultural education (Troyna, 1995:140).

There was a change in atmosphere with the election of a Labour Government in 1997, and a push towards the development of citizenship education through the establishment of an Advisory Group on Citizenship. This group published the Crick Report during the following year (QCA, 1998). The introduction of citizenship education in 2002, as an optional subject in primary schools and as a statutory part of the national curriculum for secondary schools, has given a new impetus to multicultural/intercultural education in England and Wales. Citizenship education in secondary schools requires knowledge and understanding of the diversity of national, regional, religious and ethnic identities in the United Kingdom and the need for mutual respect and understanding (DfEE/QCA, 1999a), while the non-statutory advice for primary schools encourages children to appreciate the range of national, regional, religious and ethnic identities in the United Kingdom (DfEE/QCA, 1999b). Thus, at last, a form of multicultural/intercultural education has been incorporated into the curriculum, but it needs to be developed along the lines suggested by Leicester and Rattansi and must not lapse into the simplistic multiculturalism of the 1970s. There is a clear role for specialists in religious education to contribute to this form of education (Jackson, 2003; 2004:Chapter 8).

\section{Intercultural Understanding, Religion and Social Cohesion}

The need for including the dimension of religious diversity in a critical multicultural education was reinforced by riots in the northern English towns and cities of Oldham,

General Certificate of Secondary Education examinations are taken at age 15-16.

In a letter written in 1988, Kenneth Baker, the Secretary of State for Education in England, instructed the National Curriculum Council, as it began work on the new National Curriculum, to take account of ethnic and cultural diversity and the importance of the curriculum in promoting equal opportunities for all pupils regardless of ethnic origin or gender (DES, 1988). 
Burnley, Leeds and Bradford in the summer of 2001 in areas inhabited mainly by people of Pakistani and Bangladeshi Muslim origin (Home Office, 2001a, 2001b). The causes of the riots, which mainly involved young men, included social and economic deprivation in the areas involved, as well as the political activity of the extreme right wing British National Party, which has for some time been expressing racist views in religious terms, especially through its vilification of Islam (McRoy, 2001:18-19). The Parekh Report on the future of multi-ethnic Britain draws attention to the use of religious categories in extreme right wing propaganda circulated in Britain, including a document appealing to the government to use the army to remove all mosques, temples and synagogues from this Christian land (Runnymede Trust 2000:para 17.3:237). This equation of national and Christian identity, associating all other religious identities with difference and otherness, is a version of what Tariq Modood has called cultural racism (Modood,1992; 1997). Racism directed towards religious groups, or justified on religious grounds, prompts the writers of the Parekh Report to argue that strategies for countering it need to recognise the distinctive and powerful nature of religious identity.

There had been riots in Bradford in 1995, and Lord Ouseley's report on the city of Bradford happened to be published at the same time as the 2001 riots. The Ouseley Report depressingly describes a city fragmenting along racial, cultural and faith lines, and the virtual apartheid of education (Ouseley, 2001). Two reports on the 2001 riots were commissioned by the Home Office. The report of the Ministerial Group on Public Order and Community Cohesion concludes that lack of communication contributed to the unrest, and it appeals for the promotion of dialogue between the different groups (Home Office 2001a:para 2.16:13). The second report, by an independent review team into Community Cohesion (the Cantle Report), specifically recommends educational programmes promoting cross-cultural contact (Home Office 2001b:para 5.8.18:36).

On a global scale, events such as those of 11 September 2001 in the United States of America and their aftermath, including the atrocities in Bali in the autumn of 2002, in Casablanca in May 2003, Jakarta in August 2003, Madrid in March 2004 and London in July 2005, together with the wars in Afghanistan and Iraq, have also put religion on political, social and educational agendas internationally. Indeed, in the European context, directly as a response to the events of 11 September 2001 and their consequences, the Council of Europe is encouraging the addition of the dimension of religious diversity to intercultural education, including civic education, across Europe. A project on intercultural education and the challenge of religious diversity and dialogue was approved by the education committee of the Council at the end of September 2002 (Batelaan, 2003; Jackson, 2002). This aims to produce materials for policy makers and practitioners across more than forty member states by the end of 2004 (Jackson, 2004:Chapter 10).

Motivated by a wish to establish international codes of human rights, an international project co-ordinated by the Oslo Coalition on Freedom of Religion or Belief is developing a global interdisciplinary network to encourage school education that increases understanding and respect between people of different religions or world views and that fosters knowledge about and respect for freedom of religion or belief as a human right. Through this, the project aims to combat discrimination and intolerance based on religion or belief and prevent violations of the human right to freedom of religion or belief (Jackson 2004:Chapter 10; Larsen and Plesner, 2002).

Thus, the needs of citizenship education and responses to civil unrest in Britain, reactions to international terrorism in Europe, and attempts to apply codes of human rights globally, all invite forms of intercultural education that take full account of issues in 
religious diversity, promote communication and dialogue between pupils from different backgrounds, and foster social cohesion through the encouragement of tolerance, understanding and respect between peoples. ${ }^{4}$

\section{Intercultural Education and new Pedagogies of Religious Education}

As we saw in relation to the work of Rattansi and Leicester, a critical or reflexive intercultural education needs to present more sophisticated analyses of culture than the reifications found in the multicultural education of the 1970s. Numerous ethnographic studies have informed academic discourse on the concepts of culture and cultures, and this thinking needs to be reflected in intercultural education and religious education (Jackson, 1997:Chapter 4). Such studies reflect an analysis of plurality that incorporates both traditional aspects, such as overt religious diversity and modern elements, such as competing rationalities and epistemologies and easy interpersonal contact by means of new technologies (Jackson, 2004:Chapter 1; Skeie,1995, 2002).

Gerd Baumann's analysis of cultural discourse, based on his ethnographic research in Southall, England, is particularly illuminating. Baumann distinguishes between what he calls dominant discourse in which people reify views of cultures, religions and ethnic groups, and demotic discourse, the language of interaction with others at the personal level, which creates new culture. Of course, dominant discourse in relation to culture and religion is habitually used by politicians and the media. However, Baumann found that, in certain contexts, individual inhabitants of Southall, in their own interests, also used dominant discourse, sometimes identifying themselves with categories such as Punjabi, Sikh or Asian. In different contexts, they interacted with others, creating cultural fusions and new cultural expressions. Southallians, says Baumann, engage the dominant discourse as well as the demotic one. They reify cultures while at the same time making culture (Baumann, 1996:31). The reified categories are useful reference points, but they obscure the diversity, interaction and change that is the underlying reality. As Baumann puts it, Culture...is not so much a photocopy machine but a concert or indeed a historically improvised jam session. It only exists in the act of being performed, and it can never stand still or repeat itself without changing its meaning (Baumann, 1999: 26). This second view of culture - culture as process - was absent from the multicultural education of the 1970s, and indeed from much religious education to date.

In combating the stereotypes that characterise racist language, intercultural education needs to ensure that generalised cultural and religious categories are not taken to be uniform wholes. The complexity and diversity of cultural interaction needs to be represented. Baumann gives the following advice:

Try to unreify all accepted reifications by finding crosscutting cleavages. Whenever the reifying discourse talks about citizens or aliens, purple or green ethnics, believers or atheists, ask about rich or poor citizens, powerful or manipulated ethnics, married or sexual minority believers. Who are the minorities within majorities, who are the unseen majorities right across minorities? Combine every method of questioning to every possible category around

$4 \quad$ I would add a cautionary note about the relationship between knowledge and attitudes. It is a mistake to assume that understanding and knowledge necessarily foster tolerance. There are some very well informed racists and bigots. Similarly, specialists in propaganda and spin are aware that lies and misinformation can increase tolerance, sympathy and respect. I would argue, however, that knowledge and understanding are necessary but not sufficient conditions for the genuine removal of prejudice. Moreover, not everything learned about and understood will command respect - religious education requires an analysis of the negative as well as positive influences of religion (Gearon, 2002) - and there are also limits to tolerance. 
you, for the permutations are endless when it comes to questioning reifications. (Baumann, 1999:141).

There are several recent pedagogical approaches to religious education that are consistent with Baumann's observations about cultural discourse and with critical and reflexive approaches to intercultural education. These have been developed in England and in several other northern European countries, although some related and parallel work is going on in Australia (Lovat, 2002) and South Africa (Chidester, 2003; Jackson, 2004:Chapter 6; Kwenda et al, 1997).

The interpretive approach developed at the University of Warwick in England, aims to help children and young people to find their own positions within the key debates about religious plurality (Jackson,1997; Jackson, 2004:Chapter 6). Drawing on methodological ideas from cultural anthropology, it recognises the inner diversity, fuzzy edgedness and contested nature of religious traditions, as well as the complexity of cultural expression and change from social and individual perspectives. Individuals are seen as unique, but the group tied nature of religion is recognised, as is the role of the wider religious traditions in providing identity markers and reference points. Pedagogically, the approach develops skills of interpretation and provides opportunities for critical reflection in which pupils make a constructive critique of the material studied at a distance, re-assess their understanding of their own way of life in the light of their studies and review their own methods of learning.

The Warwick RE Project is a curriculum development project that applies the interpretive approach, converting ethnographic source material into resources for use by children in class. (Barratt, 1994a,b and c; Jackson, Barratt and Everington, 1994; Mercier, 1996; Wayne et al, 1996). In designing experimental curriculum materials to help teachers and pupils to use this approach, the project team drew on ethnographic research on children related to different religious communities and groups in Britain, and on theory from the social sciences, literary criticism, religious studies and other sources (Jackson, 1997:Chapter 5). The intention was to provide a methodology that was epistemologically open and, within the limits of using books as learning resources, conversational in tone. The framework for teaching and learning encouraged sensitive and skilful interpretation, opportunities for constructive criticism (including pupils' reflections on their own use of interpretive methods), and reflection by students on what they had studied. The interpretive approach has been adapted by others, to meet particular classroom needs (Jackson, 2004:Chapter 6; Krisman, 1997; O’Grady, 2003).

In parallel with this work, members of the Institute for Comparative Religion in Southern Africa (ICRSA) have experimented with approaches to African Religion for schools that attempt to provide sound methods for its portrayal. In particular, Janet Stonier, Chirevo Kwenda and Nokuzola Mndende have attempted to write a text for students which deals both with issues of representation and interpretation. The text, African Religion and Culture Alive! (Kwenda, Mndende and Stonier, 1997) attempts to deal with African Religion as an oral tradition, with knowledge presented through myth, biographical and autobiographical stories, discussion, question and comment. The book, aimed at the upper secondary age range (16-18), is based on an edited transcript of audio-taped oral interchanges between the three authors (two South African women, one black and one white, and a black Zimbabwean man). Using a simulated, dramatised format, the book provides a context for using teaching and learning strategies employed in an oral tradition, but within the western institution of the school. As Stonier remarks: 
We hoped in this way to mirror and mediate a situation in which many South African students find themselves: At the interface between a home underpinned by an oral tradition, and a school underpinned by a written tradition (Stonier, 1996: ii)

In order to produce a text that the authors hoped would be acceptable to different varieties of African religious practice, and to encourage the collection of oral traditions, they included a primary research component. This requires students to seek out traditional elders within their communities and to collect material on the details of particular practices.

The production of the text was itself a creative exercise, using Stonier's skills as a curriculum developer, Mndende's as a teacher and practitioner of African Religion and Kwenda's as both a university lecturer in African Religion and as a Shona Chief. In producing the text, Stonier and Mndende played the role of first year university students taking a course on African Religion, and Kwenda that of professor. The format of the text was a series of unrehearsed question/answer sessions between the students and the professor, which were audio-taped and transcribed. Final amendments and refinements were also based on oral contributions. Thus the text utilised traditional African ways of learning, teaching and knowing within the context of a western university. The choice of using autobiographical material as part of interaction within a simulation was influenced by Karen McCarthy Brown's ethnographical study of Mama Lola, a Vodou priestess (Brown, 1991). Brown describes her own book as a chorus of voices - autobiographical, biographical, fictional and theoretical - and this polyphony is echoed in African Religion and Culture Alive! and in the voices of the elders via students' research. The book was one of South African religious education's first experiments in facing issues of the representation and interpretation of African Religion in a society adjusting to massive political and social change. It will provide much food for thought for future researchers and curriculum developers.

Having much in common with the interpretive approach, is a group of dialogical approaches to religious education developed independently by Julia Ipgrave in Britain, Heid Leganger-Krogstad in Norway and Wolfram Weisse and his colleagues in Germany. All claim the relative autonomy of the individual, but recognise the contextual influence of social groupings, such as family, peer, ethnic and religious groups. There is common agreement that the personal knowledge and experience that young people bring to the classroom can provide important data for study, communication and reflection. All also introduce further source material; religious education does not only consist of the analysis and exchange of personal narratives.

Julia Ipgrave conducted research on the inter-influence of children from Muslim, Hindu and Christian backgrounds in her multicultural primary school in the city of Leicester (Ipgrave, 2002), and developed an approach to RE based on her findings and on the process of conducting the research. Her pedagogy capitalises on children's readiness to engage with religious questions and their ability to utilise religious language encountered through interacting with children in school. The teacher often acts in the role of facilitator, prompting and clarifying questions, and considerable agency is given to pupils, who are regarded as collaborators in teaching and learning. Ipgrave finds that her approach raises children's self-esteem, provides opportunities to develop critical skills, allows underachievers to express themselves and generates a climate of moral seriousness through the discussion of basic human questions (Ipgrave, 2001; 2003; Jackson, 2004:Chapter 7).

Ipgrave's research project developed a threefold approach to dialogue which has been incorporated into the pedagogical work derived from it. Primary dialogue is the acceptance of diversity, difference and change. Secondary dialogue involves being open to and positive 
about difference - being willing to engage with difference and to learn from others. Tertiary dialogue is the actual verbal interchange between children. The basic activity here is discussion and debate. Throughout the approach encourages personal engagement with ideas and concepts from different religious traditions and children are encouraged to be reflective about their contributions - and to justify their own opinions. They are also encouraged to consider how they arrived at their conclusions, to recognise the possibility of alternative viewpoints and to be open to the arguments of others. Ipgrave has now extended this approach through the use of e-mail communication between children from different backgrounds in schools in Leicester and East Sussex.

Heid Leganger-Krogstad developed her dialogical approach in northern Norway. RE moves between the child's personal experience and wider social experience and between the past - in terms of tradition and history, especially the children's own roots - and the future. There is a gradual broadening of children's experience as they relate their personal concerns to selected cultural material, extending their horizons beyond family and locality to the region and nation and, in turn, to wider European and global issues. Pupils' individual concerns and questions are related to broader social and cultural issues, with local issues acting as a bridge. Children's dialogue, whether within their own culture - in recognising its internal diversity - or between cultures is seen as a key element in developing what Leganger-Krogstad calls metacultural competence, the ability to handle new and unfamiliar cultural material with skill and sensitivity (Jackson, 2004:Chapter 7; Leganger-Krogstad, 2000; 2001).

Developed in the multicultural city of Hamburg, Wolfram Weisse's approach to what he calls intercultural/interreligious learning, combines elements of religious education and education for citizenship (Weisse, 1996a; 1996b; 2003). Weisse's approach, ethically grounded in human rights codes, aims to foster communication within multicultural societies. Weisse sees issues such as relativism, undermining faith and challenging the absoluteness of Christianity as part of the debate that young people should engage in:

While the spectrum of topics points to the many similarities between the religions, dialogue in $\mathrm{RE}$ is also designed to demonstrate the differences between religious traditions. Individual positions are not found by mixing different views, but by comparing and contrasting them with one another. Religious education should make dialogue in the classroom possible by allowing participants to refer to their different religious backgrounds... Dialogue in the classroom fosters respect for other religious commitments, can confirm pupils' views or help them to make their own commitments whilst also allowing them to monitor their commitments critically (Weisse, 2003: 194).

Pupils practise the skills of listening, of comparing and contrasting their own views with those of others, and of empathy. Difference is recognised, and pupils are encouraged to find their own epistemological standpoint. Weisse recognises that dialogue in school can lead to conflict. This is regarded as normal, and conflicts are worked through as part of religious education, with students sometimes having to agree and accept that differences cannot be resolved. (Weisse, 1996b:275-6, 2003).

Although there are some differences in these pedagogical approaches, they all share stances on the analysis of cultural and religious discourse and views about the agency of pupils with writers on critical or reflexive multicultural education. Their work in religious education makes a direct contribution to the goals of intercultural education. Some religious education specialists are already working with colleagues from intercultural education and related fields, in the Council of Europe and Oslo Coalition projects outlined above, for example. There is, however, scope for further creative collaborations. 


\section{Conclusion}

Both intercultural/multicultural education and religious education have changed significantly since the 1970s. Both now include theoretical frameworks and pedagogies that take account of the complexities of plurality and incorporate sophisticated analyses of culture. Tragic events within Britain and internationally have pointed to the need to give more attention to the religious dimension of social life in educational programmes. Home Office Reports following riots in England recognise the religious elements in the conflict and recommend the promotion of dialogue and cross-cultural contact in education. ${ }^{5}$ The Council of Europe and Oslo Coalition projects also grasp the importance of the religious dimension to intercultural and human rights education. Interpretive and dialogical approaches to religious education are among those that can contribute positively and directly to intercultural education, through their underlying empirical research, theory and their pedagogies. There are also opportunities for collaborative work between scholars and researchers in the two fields.

\section{BIBLIOGRAPHY}

Batelaan, P 2003. Intercultural education and the challenge of religious diversity and dialogue in Europe. Upublished discussion paper, Directorate of School, Out of School and Higher Education, Strasbourg, Council of Europe, Strasbourg, Council of Europe.

Ball, S 1990. Politics and Policy Making in Education. London: Routledge.

Barratt, M 1994a. Something to Share, Bridges to Religions series. The Warwick RE Project, Oxford: Heinemann.

-- 1994b. The Buddha's Birthday, Bridges to Religions series, The Warwick RE Project, Oxford: Heinemann.

-- $\quad$ 1994c. The Seventh Day is Shabbat, Bridges to Religions series. The Warwick RE Project, Oxford: Heinemann.

Baumann, G 1996. Contesting Culture: Discourses of Identity in Multi-Ethnic London. Cambridge: Cambridge University Press.

-- $\quad$ 1999. The Multicultural Riddle: Rethinking National, Ethnic and Religious Identities. London: Routledge.

Brown, KM 1991. Mama Lola: A Vodou Priestess in Brooklyn. Berkeley: University of California Press.

Chidester, D 2003. Religion education in South Africa: teaching and learning about religion, religions and religious diversity. British Journal of Religious Education. 25(4):261-278.

Cole, WO 1972. Religion in the Multifaith School, (1 $1^{\text {st }}$ ed.). Bradford: Yorkshire Committee for Community Relations.

Cox, E 1967. Sixth Form Religion. London: SCM.

DES 1977. Education in schools: a consultative document. London, HMSO.

5 The formation of a youth shadow Standing Advisory Council for Religious Education (SACRE) in the city of Bradford, which gives responsibility to young people from different backgrounds to interact with one another in helping to plan and monitor religious education, is one positive response to such recommendations (Miller, 2003). 
DES 1988. Letter to National Curriculum Council from Kenneth Baker, Secretary of State for Education. York, NCC.

DfEE/QCA 1999a. The National Curriculum for England: Citizenship. London: Department for Education and Employment and Qualifications and Curriculum Authority.

DfEE/QCA 1999b. The National Curriculum for England: Non-statutory Frameworks for Personal, Social and Health Education and Citizenship at Key Stages 1 \& 2; Personal, Social and Health Education at Key Stages 3 \& 4. London: Department for Education and Employment and Qualifications and Curriculum Authority.

Gearon, L 2002. Religious education and human rights: some postcolonial perspectives. British Journal of Religious Education. 24(2):140-51.

Graham, D 1993. A Lesson for Us All: The Making of the National Curriculum. London, Routledge.

HOME OFFICE 2001a. Building Cohesive Communities: A Report of the Ministerial Group on Public Order and Community Cohesion. December, London: Home Office.

HOME OFFICE 2001b. Community Cohesion: A Report of the Independent Review Team chaired by Ted Cantle. December, London: Home Office.

Ipgrave, J 2001. Pupil to Pupil Dialogue in the Classroom as a Tool for Religious Education. Warwick Religions and Education Research Unit Occasional Papers II. University of Warwick, Institute of Education.

-- 2002. Inter faith encounter and religious understanding in an inner city primary school. Unpublished PhD thesis, University of Warwick.

-- 2003. Dialogue, citizenship and religious education. International Perspectives on Citizenship, Education and Religious Diversity, eds. Jackson, R. London: RoutledgeFalmer. 147-68.

Jackson, R 1997. Religious Education: An Interpretive Approach. London: Hodder and Stoughton.

-- 2002. Intercultural Education and the Challenge of Religious Diversity and Dialogue: A Response. Unpublished Report for Head of Educational Policies and European Dimension Division in the Directorate of School, Out of School and Higher Education, Strasbourg, Council of Europe.

-- 2003. (ed.) International Perspectives on Citizenship, Education and Religious Diversity. London: RoutledgeFalmer.

-- $\quad$ 2004. Rethinking Religious Education and Plurality: Issues in Religious Diversity and Pedagogy. London: RoutledgeFalmer.

Jackson, R, Barratt, M and Everington, J 1994. Bridges to Religions: Teacher's Resource Book. The Warwick RE Project, Oxford: Heinemann.

Krisman, A 1997. Speak from the Heart: Exploring and Responding to RE in the Special School. Oxford: Farmington Institute for Christian Studies. Online: http://www.farmington.ac.uk/documents/reports/framed/teaching_training.html (accessed August 2003)

Kwenda, C, Mndende, N and Stonier, J 1997. African Religion and Culture Alive! Hatfield (SA): Collegium. 
Larsen, L and Plesner, IT (eds.) 2002. Teaching for Tolerance and Freedom of Religion or Belief, Oslo: The Oslo Coalition on Freedom of Religion and Belief, University of Oslo.

Leganger-Krogstad, H 2000. Developing a contextual theory and practice of religious education. Panorama: International Journal of Comparative Religious Education and Values. 12(1):94-104.

-- 2001. Religious education in a global perspective: a contextual approach, Towards Religious Competence: Diversity as a Challenge for Education in Europe eds. Heimbrock, H-G, Schreiner, P \& Sheilke, C. Towards Religious Competence: Diversity as a Challenge for Education in Europe, Hamburg: Lit Verlag. 53-73.

Leicester, M 1992. Antiracism versus the new multiculturalism: moving beyond the interminable debate. Cultural Diversity and the schools: Equity or Excellence? Education and Cultural Reproduction, eds. Lynch, J, Modgil, C \& Modgil, S. London: Falmer.

Lovat, T 2002. Religious education: robust and bold for a multifaith era. Journal of Religious Education. 50(3):29-35.

Mcintyre, J 1978. Multi-Culture and Multifaith Societies: Some Examinable Assumptions. Occasional Papers, Oxford: Farmington Institute for Christian Studies.

McRoy, A 2001. BNP's anti-Muslim Crusade Q News. The Muslim Magazine. 18-19.

May, S (ed.) 1999. Critical Multiculturalism: Rethinking Multicultural and Antiracist Education. London: Falmer Press.

Meijer, WAJ 1995. The plural self: a hermeneutical view on identity and plurality, British Journal of Religious Education. 17(2):92-99.

Mercier, C 1996. Muslims, Interpreting Religions series. The Warwick RE Project, Oxford: Heinemann.

Miller, J 2003. Faith and belonging in Bradford. RE Today 20(3):34.

Modood, T 1992. On not being white in Britain: discrimination, diversity and commonality. Ethics, Ethnicity and Education, eds. Leicester, M \& Taylor, M. London: Kogan Page. 72-87.

-- $\quad$ 1997. "Difference", cultural racism and antiracism. Debating Cultural Hybridity, eds. Werbner, P \& Modood T. London: Zed Books. 154-72.

Mullard, C 1984. Anti-Racist Education: The Three O's. Cardiff: National Association for Multiracial Education.

O'Grady, K 2003. Motivation in religious education: a collaborative investigation with year eight students. British Journal of Religious Education, 25(3):214-25.

Ouseley H. (ed.) 2001. Community Pride Not Prejudice: Making Diversity Work in Bradford. Bradford: Bradford Vision.

QCA 1998. Education for Citizenship and the Teaching of Democracy in Schools. Final Report of the Advisory Group on Citizenship, London: Qualifications and Curriculum Authority.

Rattansi, A 1992. Changing the subject: racism, culture and education. Race Culture and Difference, eds. Donald, J \& Rattansi, A. London: Sage in association with The Open University:11-48. 
-- $\quad$ 1999. Racism, postmodernism and reflexive multiculturalism. Critical

Multiculturalism: Rethinking Multicultural and Antiracist Education, ed. May S.

London: Falmer Press.

Richardson, R 1990. Daring to be a Teacher. Stoke on Trent: Trentham.

Runnymede Trust 2000. The Future of Multi-Ethnic Britain: The Parekh Report. London: Profile Books.

Schools-Council 1971. Religious Education in Secondary Schools, Schools Council Working Paper 36, London: Evans/Methuen.

Skeie, G 1995 Plurality and pluralism: a challenge for religious education, British Journal of Religious Education. 25(1):47-59.

-- $\quad 2002$. The concept of plurality and its meaning for religious education, British Journal of Religious Education. 25(2):47-59.

Stonier, J 1996. Oral into written: an experiment in creating a text for African religion. Unpublished MA dissertation, University of Cape Town.

Tomlinson, S and Craft, M (eds) 1995. Ethnic Relations and Schooling: Policy and Practice in the 1990s, London: The Athlone Press.

Troyna, B 1983. Multiracial education: just another brick in the wall? New Community. 10:424-8.

-- 1995. The Local Management of Schools and Racial Equality. Ethnic Relations and Schooling: Policy and Practice in the 1990s, eds. Tomlinson, S. \& Craft, M. London, The Athlone Press.. 40-54.

Wayne, E, Everington, J, Kadodwala, D and Nesbitt, E 1996. Hindus, Interpreting Religions series, The Warwick RE Project, Oxford: Heinemann.

Weisse, W 1996a. Approaches to religious education in the multicultural city of Hamburg. Interreligious and Intercultural Education: Methodologies, Conceptions and Pilot Projects in South Africa, Namibia, Great Britain, the Netherlands and Germany, ed. Weisse, W. Münster: Comenius Institut. 83-93.

-- $\quad 1996 b$. Christianity and its neighbour-religions: a question of tolerance? Scriptura: International Journal of Bible, Religion and Theology. 55(4):263-76.

-- 2003. Difference without discrimination: religious education as a field of learning for social understanding? International Perspectives on Citizenship, Education and Religious Diversity, ed. Jackson, R. London: RoutledgeFalmer.191-208. 